\title{
Seasonality of honey bee colony invasion by Varroa jacobsoni Oud
}

\author{
F Sakofski ${ }^{*}, \mathrm{~N}$ Koeniger, S Fuchs \\ Institut für Bienenkunde (Polytechnische Gesellschaft), FB Biologie der JW Goethe-Universität, \\ Frankfurt/Main, D-6370 Oberursel, Karl-von-Frisch-Weg 2, Germany
}

(Received 10 October 1990; accepted 29 October 1990)

\begin{abstract}
Summary - Invasion of Varroa jacobsoni into Apis mellifera colonies was monitored using Bayvarol-strips for 2 years from April to October. The seasonal profile of mite invasion was similar in all colonies. Invasion was low in spring and increased considerably during summer when it remained at high levels until autumn. Mite invasion into the monitored colonies correlated closely with the infestation level of the apiaries, but varied considerably between monitor colonies.
\end{abstract}

Varroa jacobsoni / spread / infestation / seasonality

\section{INTRODUCTION}

Recently, efficient carrier methods have been developed using contact acaricides for the control of Varroa jacobsoni (Koeniger and Fuchs, 1988). The efficacy of these methods has been estimated at about $99.8 \%$. The carriers are placed in the center of the hive where the acaricide is distributed by contact with bees, thus maintaining an effective level of acaricide within the colony during an extended period. As Varroa mites are rapidly killed, this method allows the invasion of bee colonies by the parasite to be monitored.

Varroa is predominantly transported into colonies by worker bees. Drifting of infested bees from other colonies could be shown to contribute substantially to the spread of $V$ jacobsoni, but mites are also introduced from other colonies by homing forager bees into their own colony (Sakofski and Koeniger, 1988). In addition, substantial numbers of mites can be transported into a colony by the robbing of highly infested colonies close to breakdown (Sakofski, 1990).

The transfer of mites between colonies is an important factor interfering with the control of the disease. To quantify mite invasion into colonies in relation to the season, the invasion of Varroa into colonies was monitored over a period from spring to autumn.

\section{METHODS}

The weekly invasion of bee hives by Varroa jacobsoni was recorded using colonies contain-

\footnotetext{
* Correspondence and reprints.
} 
ing Bayvarol-strips. Each monitor colony was 2fold overdosed using 8 strips, each containing $3.6 \mathrm{mg}$ flumethrin. To maintain the acaricide efficacy the carriers were replaced by new ones every 8 th week.

In 1987, 3 monitor colonies were always placed in 2 apiaries. In 1988, 2 colonies were placed in 5 apiaries, one colony placed in between the row of infested colonies (=In), the other at a distance of approx $10 \mathrm{~m}$ (=Out).

Sheets fitting the hive bottom exactly were used to collect the dead mites from the colony. The sheets were spread with Vaseline and covered by $2 \times 2 \mathrm{~mm}$ gauze net to prevent bees from carrying out dead mites. In previous tests using 6 colonies, 363 of a total of 404 mites introduced on bees were recovered within $24 \mathrm{~h}$ $(90.4 \pm 5.2 \%)$.

Dead mites were counted weekly on the sheets. In 1988, the infested colonies in the apiaries were treated at the end of the observation period using Bayvarol-strips and dead mites were recorded.

\section{RESULTS}

Experiments were begun in April and terminated in October. Only few mites per week were recorded in early spring (fig 1 , 1987: $2.3 \pm 2.7,1988: 3.0 \pm 5.9$ ), with a considerable increase in early summer (1987: $10.2 \pm 6.0,1988: 11.0 \pm 10.8$ ) and a further increase in late summer (1987: $32.8 \pm 23.7,1988: 26.2 \pm 27.7$ ). Numbers of recorded mites decreased again in autumn (1987: $8.3 \pm 3.7,1988$ : $15.8 \pm 20.4$ ). In both years, the time course of Varroa invading the monitor colonies was roughly similar. Differences between years were not significant in relation to the above seasons (2-way ANOVA). Combining the data of both years, each of these seasons differed significantly from the previous one $(p$ $<0.05$, Scheffe multiple range test).

At the end of the 1988 experiment the infested colonies at the 5 apiaries were treated with Bayvarol-strips. Table I gives the average of the dead mites from these treatments and the totals of mites recorded in the monitor colonies during the entire season. Both measures are highly correlated $(r=0.997, p<0.01)$. Numbers of mites differed over a wide range between monitor colonies in the same apiary, and no difference was apparent in relation to their

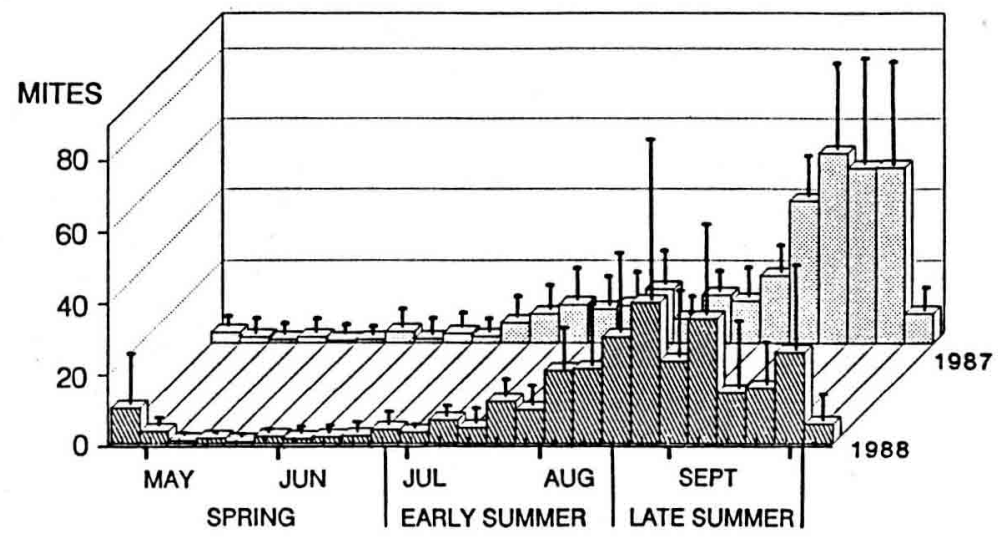

Fig 1. Numbers of Varroa mites monitored weekly from April to October during 1987 and 1988. Abscissa : time of year. Ordinate : means and standard deviations from all monitor colonies, 1987: $n=$ 6; $1988: n=10$. 
Table I. Means and standard deviations of Varroa mites killed during autumn treatment in the infested colonies of the apiaries $A-E$ and total numbers of mites invading the monitor colonies. MC In: Monitor colony placed inside the row; MC Out : Monitor colony placed approx $10 \mathrm{~m}$ apart.

\begin{tabular}{lllll}
\hline $\begin{array}{c}A \\
(n=5)\end{array}$ & $\begin{array}{c}B \\
(n=4)\end{array}$ & $\begin{array}{c}C \\
(n=6)\end{array}$ & $\begin{array}{c}D \\
(n=10)\end{array}$ & $\begin{array}{c}E \\
(n=9)\end{array}$ \\
\hline $\begin{array}{l}\text { Infested colonies } \\
942.6 \pm 312.5\end{array}$ & $705.3 \pm 651.5$ & $908.8 \pm 261.0$ & $3142 \pm 715.1$ & $1939.6 \pm 732$ \\
$\begin{array}{l}\text { MC In: } \\
142\end{array}$ & 191 & 193 & & 334 \\
$\begin{array}{l}\text { MC Out : } \\
214\end{array}$ & 231 & 165 & 410 & 405 \\
\hline
\end{tabular}

position within the row of colonies (In) or apart (Out).

\section{DISCUSSION}

The seasonal pattern of the mite transfer of all colonies showed a similar time course: low values in spring, high values in summer until autumn, with a following decrease. This time course at least partly reflects the population buildup of $V$ jacobsoni in the infested colonies.

It seems, however, to be additionally related to the influence of the bee season and the likelihood of bees entering other colonies. During spring drifting of bees is only occasional, but increases at the end of nectar flow during July. A marked robbing tendency can be observed during August and September when there is almost no nectar flow. Robbing ceases during October, when flight activity is reduced. The apparent differences between monitor colonies within one apiary might be related to their inclination to rob.

A third factor to be considered is that high infestation of worker bees could increase their tendency to enter other colo- nies (Sakofski, 1990). In August and September, Varroa populations reach their maximum. At the same time brood activity ceases, resulting in a concentration of the mites on worker bees.

The numbers of transferred mites correlated strongly with the average infestation of the neighbouring colonies. These results are consistent with those of Ritter (1987), who showed an increase in Varroa population buildup caused by highly infested colonies in the vicinity.

The annual time course indicates that during spring, the risk of infestation by high numbers of mites is comparatively low, whereas colonies treated early in summer might become reinfested by considerable numbers of Varroa during the summer.

\footnotetext{
Résumé - Infestation saisonnière de colonies par Varroa jacobsoni. On a suivi l'évolution hebdomadaire du nombre de varroas pénétrant dans les colonies d'abeilles à l'aide de bandelettes au Bayvarol. Jusque fin juin, l'infestation est restée faible; elle a atteint des niveaux élevés en août et septembre puis a rediminué. Elle dépendait étroitement de l'infestation des colonies avoisinantes.
} 
Varroa jacobsoni / infestation / propagation / variation saisonnière

Zusammenfassung - Saisonale Abhängigkeit der Invasion von Bienenvölkern durch Varroa jacobsoni. Die Anzahl wöchentlich in Bienenvölker eindringender Varroa jacobsoni wurde durch mit Bayvarol-Streifen versehene Bienenvölker kontinuierlich registriert. Die Invasion war bis Ende Juni gering und erreichte hohe Werte während des August und September. Danach nahm sie wieder ab. Es bestand eine klare Abhängigkeit von dem Befall der benachbarten Völker.

Varroa jacobsoni / Befall / Verbreitung / Saisonale Abhängigkeit

\section{REFERENCES}

Koeniger N, Fuchs (1988) Control of Varroa jacobsoni Oud in honeybee colonies containing sealed brood cells. Apidologie 19, 117-130

Ritter W (1987) Entwicklung der Bienen- und Varroamilbenpopulation in Gebieten mit unterschiedlichen Möglichkeiten der Reinvasion. Tierärzt Umschau 42 (7), 548-551

Sakofski F, Koeniger N (1988) Natural transfer of Varroa jacobsoni between honeybee colonies in autumn. In: European Research on Varroatosis Control (Cavalloro R, ed) Balkema, Rotterdam, 81-83

Sakofski F (1990) Quantitative Untersuchung der Übertragungswege der parasitischen Milbe Varroa jacobsoni Oud zwischen Völkern der Honigbiene Apis mellifera L. PhD Thesis, JW Goethe-Universität, Frankfurt/ Main,Germany 